\title{
MĀKSLİGAIS INTELEKTS UN NĀKOTNES REGULĒJUMA DILEMMA
}

\section{ARTIFICIAL INTELLIGENCE AND FUTURE REGULATORY DILEMMA}

\author{
Ritvars Purmalis, Mg. iur. \\ Latvijas Universitātes Juridiskās fakultātes doktorants
}

\begin{abstract}
Summary
Digital innovations such as artificial intelligence systems, although limited in their current operational capacity, can be considered to be part of our daily life. Various ways in which these systems are implemented into day-to-day aspects directly affect not only the further development of the industrial sector but the society as a whole. The purpose of this article is to provide a brief insight into the current situation and the various initiatives of the European Union institutions in relation to the methodology for the application of civil liability in the case of damage caused by artificial intelligence systems, as well as to assess the content of future regulatory framework that has been published by the European Parliament, with whom it is intended to establish a common methodology throughout the European Union for the application of civil liability regime, if the damage is caused by artificial intelligence systems.
\end{abstract}

Atslēgvārdi: mākslīgais intelekts, vainojamības modelis, stingrā atbildība, kaitējums, saprātīga persona.

Keywords: artificial intelligence, fault-based liability, strict liability, damage, reasonable person.

\section{Ievads}

Neapšaubāmi var apgalvot, ka tādas digitālās inovācijas kā mākslīgā intelekta vadītas sistēmas, kaut arī limitētā darbības kapacitātē, tomēr ir uzskatāmas par daḷu no mūsu ikdienas. Minēto sistēmu lietošana jau šobrīd ietekmē vairākus ar sabiedrību un rūpniecības nozari saistītus aspektus, kā piemēru var minēt mākslīgā intelekta vadītu sistēmu lietošanu zinātnes attīstības veicināšanā un veselības aprūpes pilnveidēe, ${ }^{1}$ kà arī infekciozu slimību paveidu atklāšanā. ${ }^{2}$ Var

${ }^{1}$ Sk., piemēram: Perc M., Ozer, M., Hojnik, J. Social and juristic challenges of artificial intelligence. Palgrave Communications 5, article number: 61, 2019. Pieejams: https://www.nature.com/articles/s41599-0190278-x [aplūkots 07.03.2021.].

2 Yang Z., Bogdan P., Nazarian S. An in silico deep learning approach to multi-epitope vaccine design: a SARS-CoV-2 case study. Scientific Reports, 11, article number: 3238, 2021. Pieejams: https://www.nature.com/articles/s41598-021-81749-9 [aplūkots 18.02.2021.]; sk. arī: Malone B., Simovski B., Moliné C. Artificial intelligence predicts the immunogenic landscape of SARS-CoV-2 leading to universal blueprints for vaccine designs. Scientific Reports, 10, article number: 22375, 2020. Pieejams: https://www.nature. 
piekrist viedoklim, ka laika gaitā mākslīgā intelekta vadītas sistēmas kḷūs par tikpat ierastu parādību kā internets vai plašsaziṇas līdzekḷi. ${ }^{3}$ Tomēr bez ievērības nevar atstāt iespējamos kaitējuma nodarīšanas riskus, ko tikpat labi varētu radīt kḷūdaina informācijas apstrāde un nevis tas, vai minētās sistēmas darbība netieši ir bijusi pakḷauta konkrētas personas kontrolei. Minētais savukārt ir bijis pamats tam, lai relatīvi ilgstošā laika posmā Eiropas Savienības institūcijas pārvērtētu ar civiltiesiskās atbildības piemērošanu saistītus aspektus, kā arī to, kurš no civiltiesiskās atbildības modeḷiem - vainojamības modelis vai stingrā atbildība būtu uzskatāms par atbilstošāku, lai korekti adresētu civiltiesiskās atbildības piesaisti konkrētai personai gadījumā, ja kaitējumu ir nodarījusi mākslīgā intelekta vadìta sistēma.

Raksta mērḳis ir sniegt vērtējumu par Eiropas Parlamenta publicētā iespējamā nākotnes regulējuma priekšlikuma saturu, ar kuru ir paredzēts visā Eiropas Savienībā noteikt vienotu civiltiesiskās atbildības piemērošanas metodiku mākslīgā intelekta vadìtas sistēmas nodarìta kaitējuma gadījumā, kā arī atbildēt uz jautājumu, vai iespējamā nākotnes regulējuma priekšlikuma saturs būtu pilnveidojams. Raksta mērķa sasniegšanai izmantoti Eiropas Savienības institūciju politikas plānošanas dokumenti, tiesību doktrīnā paustās atziṇas, kā arī autora personiskā arhīva materiāli. Rakstā lietota analītiskā, salīdzinošā un dedukcijas metode.

\section{Pašreizējās situācijas raksturojums}

Pašreizējās situācijas kontekstā norādāms, ka 21. gadsimta atklājumi māk slīgā intelekta vadìtu sistēmu jomā veicina minēto sistēmu spēju pieṇemt patstāvīgus, iepriekš neparedzamus lēmumus bez citas personas iesaistes. ${ }^{4}$ Tomēr, neskatoties uz mākslīgā intelekta vadītu sistēmu darbības specifikas rezultātā radītajiem izaicinājumiem civiltiesiskās atbildības piemērošanas iespējamībā, ${ }^{5}$ no publiskajā telpā pieejamās informācijas neizriet, ka Eiropas Savienības dalībvalstis būtu izstrādājušas īpašu civiltiesiskās atbildības regulējumu vai arī pilnveidojušas (pielāgojušas) esošo nacionālā regulējuma ietvaru attiecībā uz civiltiesiskās atbildības piemērošanas metodiku mākslīgā intelekta nodarīta kaitējuma gadījumā. Vienlaikus, kaut gan netiek apšaubìts tas, ka arī rūpīgi

com/articles/s41598-020-78758-5 [aplūkots 18.02.2021.]. Tāpat arī ar Exscalate platformas starpniecību tiek nodrošināts, ka virtuālas sijājošās diagnostikas jeb skrīninga rezultātā vienā sekundē tiek apstrādāts ievērojams informācijas kopums, tādējādi paātrinot laboratorisko pētijumu termiṇus medikamentu izstrādei cīṇā pret Covid-19. Turklāt minētā Exscalate platforma jau vēsturiski tika izmantota, lai atrastu nepieciešamos medikamentu savienojumus cinņā pret Zikas vīrusu. Pieejams: https://www.exscalate4cov. eu/ [aplūkots 27.02.2021.]; sk. sīkāk: European Commission. Second European AI Alliance Assembly: Event Report. Brussels, 2020, p. 10. Pieejams: https://futurium.ec.europa.eu/en/european-ai-alliance/ document/2nd-european-ai-alliance-assembly-event-report [aplūkots 27.02.2021.].

${ }^{3}$ Sk.: Haenlein M., Kaplan A. A Brief History of Artificial Intelligence: On the Past, Present, and Future of Artificial Intelligence. California Management Review, Vol. 61, No. 4, 2019, p. 9. Pieejams: https:// journals.sagepub.com/doi/abs/10.1177/0008125619864925?journalCode $=$ cmra [aplūkots 28.02.2021.].

${ }^{4}$ Sk. sīkāk: Kārkliņš J., Purmalis R. Mākslīgais intelekts un civiltiesiskā atbildība. Grām.: Starptautisko un Eiropas Savienības tiesību piemērošana nacionālajās tiesās. Latvijas Universitātes 78. starptautiskās zinātniskās konferences rakstu krājums. Rīga: LU Akadēmiskais apgāds, 2020, 245. lpp.

${ }^{5}$ Sk., piemēram: European Commission. Liability for Artificial Intelligence and other emerging digital technologies. Report from the Expert Group on Liability and New Technologies - New Technologies Formation. 2019, pp. 15-30. Pieejams: https://ec.europa.eu/transparency/regexpert/index.cfm?do= groupDetail.groupMeetingDoc\&docid=36608 [aplūkots 07.04.2021.]. 
izstrādāts likums nevar saturēt risinājumu katram dzīves gadijumam ${ }^{6}$ un ka likuma objektīvā "nepilnība" ir skaidrojama ar nepārtraukto sabiedrības sociālo, tehnisko, saimniecisko un politisko attīstību, ${ }^{7}$ tomēr, autora ieskatā, nav piel̦aujama situācija, kurā civiltiesiskās atbildības piesaistes pamatjautājumi ilgtermiṇā tiktu risināti vienīgi tiesību tālākveidošanas cel̦ā.

Ievērojot apstākli, ka pašreiz normatīvajos aktos nav atrodama nedz mākslīgā intelekta vadītas sistēmas definīcija, nedz arī konkrēts pienākumu kopums minēto sistēmu operatoriem, civiltiesiskās atbildības piemērošanas kontekstā tiek radīta problemātika. ${ }^{8}$ Kā zināms, tad vainojamības modelī bez cēloniskā sakara un kaitējuma esamības civiltiesiskās atbildības piemērošana mākslīgā intelekta vadìtas sistēmas operatoram ir atkarīga no tā, vai ir iespējams konstatēt minētās sistēmas operatora neuzmanību vai l̦aunu nolūku. Neuzmanību konstatē, balstoties uz objektīviem uzvedības standartiem, proti, kā būtu rīkojusies vidusmēra saprātīga persona, ${ }^{9}$ savukārt ḷaunu nolūku - pēc minētās sistēmas operatora psihiskās attieksmes pret tā ìstenoto nodarījumu. ${ }^{10}$ Jāṇem vērā, ka minētais "saprātīgas personas standarta" izvērtējums atzīstams par visnotal sarežgìitu procesu, kurā jāvērtē tādi elementi kā aizsargājamo interešu raksturs un vērtība, īstenotās darbības bīstamība, personas spēja novērtēt bīstamību, nodarītā kaitējuma paredzamība, iesaistīto personu attiecību raksturs, piesardzības iespējas un to pieejamība, ${ }^{11}$ un ne tikai tas. Minētais savukārt l̦auj atzìt, ka mākslīgā intelekta vadītas sistēmas operatora civiltiesiskās atbildības noteikšana vainojamības modelī, lai arī iespējama, varētu būt visnotaḷ izaicinoša. Turklāt kontekstā ar mākslīgā intelekta vadītas sistēmas spēju funkcionēt autonomi bez ievērības nevar atstāt apstākli, ka, saskaṇā ar Latvijas privāttiesību regulējumu, civiltiesiskā atbildība par minētās sistēmas operatora bezdarbību iestātos vienīgi gadījumā, ja tiktu pārkāpta pienākumu uzliekoša tiesību norma. ${ }^{12}$

Savukārt civiltiesiskās atbildības piemērošana stingrās atbildības modelī saistāma ar noteikta mākslīgā intelekta vadìtai sistēmai raksturīgā riska materializēšanos, kas ir atzīstams par cēloni nodarītajam kaitējumam trešajai personai. Atškìrībā no atbildības par vainojamību, kurā attaisnojumu uzskaitījums normatīvajos aktos nav izsmel̦ošs, stingrās atbildības modelī, lai neiestātos mākslīgā intelekta vadītas sistēmas operatora civiltiesiskā atbildība, var izmantot vienīgi normatīvajos aktos konkrēti nosauktus attaisnojuma pamatus. ${ }^{13}$ Citiem vārdiem, stingrās atbildības gadījumā nav jāvērtē mākslīgā intelekta vadītas sistēmas operatora īstenotās

${ }^{6}$ Neimanis J. Ievads tiesībās. Rīga: zv. adv. J. Neimanis, 2004, 170. lpp.

${ }^{7}$ Kalniņš E. Tiesību tālākveidošana. Grām.: Juridiskās metodes pamati. 11 soḷi tiesỉbu normu piemērošanā: Rakstu krājums profesora Edgara Meḷkiša zinātniskā redakcijā. Rīga: Latvijas Universitāte, 2003, 127. lpp.

8 Sk. sīkāk: Kārkliņš J., Purmalis R. 2020, 245.-250. lpp.

${ }^{9}$ Sk. sīkāk: Torgāns K., Kārkliņš J., Bitāns A. Liggumu un deliktu problēmas Eiropas Savienībā un Latvijā. Rīga: Tiesu namu ağentūra, 2017, 111. lpp.; sk. arī: Cees van Dam. European Tort Law. Second Edition. Oxford: University Press, 2013, p. 234.

${ }^{10}$ Sk. sīkāk: Torgāns K., Kārkliņš J., Bitāns A. 2017, 111. lpp.; sk. arī: Kārkliņš J. Vainas, prettiesiskas rīcības un atbildības ideja privāttiesỉbās. LU žurnāls "Juridiskā zinātne”, Nr. 8. Rịga: LU, 2015, 156. lpp.

${ }^{11}$ Minētais piemērveida uzskaitijums izriet no Eiropas deliktu tiesību principu 4:102. panta. Pieejams: http://www.egtl.org/docs/PETL.pdf [aplūkots 14.03.2021.]; sk. sīkāk: Torgāns K., Kārkliņš J., Bitāns A. 2017, 288. lpp.; sk. arī: Kārkliņ̌̌ J. Neuzmanības jēdziens saistỉbu tiesībās. Grām.: Latvijas Republikas Satversmei - 95. Latvijas Universitātes 75. zinātniskās konferences rakstu krājums. Rīga: LU Akadēmiskais apgāds, 2017, 45.-49. lpp.

12 Kārkliņš J. 2015, 159. lpp.

13 Torgāns K., Kārklinšs J. Civiltiesiskās atbildības modeli pēc vainojamības pazīmes. Jurista Vārds, 08.09.2015., Nr. 35 (887). Pieejams: www.juristavards.lv. [aplūkots 06.04.2021.]. 
darbības vai bezdarbības atbilstība minētajam "saprātīgas personas standartam", bet gan jāpārliecinās, vai nav konstatējami normatīvajos aktos noteikti attaisnojuma pamati civiltiesiskās atbildības nepiemērošanai. ${ }^{14}$ Saistībā ar minēto varētu uzdot provokatīvu jautājumu - kuras pienākumu uzliekošās tiesību normas vai kādi normatīvajos aktos noteiktie attaisnojuma pamati būtu attiecināmi uz attiecīgo kategoriju lietām?

Kā to pamatoti atzinis profesors Dr. iur. Jānis Kārkliņš intervijā ar raksta autoru, tad "civiltiesiskās atbildības noteikšana vainojamības modelī būtībā nav piemērota konkrētas personas atbildības noteikšanai par mākslīgā intelekta vadītas sistēmas nodarītu kaitējumu citai personai [..] minētais galvenokārt ir saistāms ar apsvērumu, ka mākslīgā intelekta vadīta sistēma tās darbībā ir atzīstama par patstāvīgu objektu, kas vienlaikus var būt tikpat neprognozējama kā tiesību subjekts [..] turklāt bez ievērības nevar atstāt to, ka vainojamības modelī civiltiesiskās atbildības piesaiste konkrētai personai ir konstruēta tādējādi, ka piemērojamās civiltiesiskās atbildības apmēru ietekmē katras personas spējas modelēt mūsdienu sabiedrībā nepieciešamā "rūpības standarta" tvērumu katrā konkrētajā dzīves situācijā"15. Savukārt docents Dr. iur. Erlens Kalniņš intervijā ar autoru paudis viedokli, ka "konkrētas personas civiltiesisko atbildỉbu par mākslīgā intelekta vadītas sistēmas nodarītu kaitējumu trešajai personai būtu jāizvērtē nevis vainojamības modelī, bet gan civiltiesībās zināmajā stingrās atbildības modelī, ko savukārt pamato apsvērums, ka mākslīgā intelekta vadìtas sistēmas spēja funkcionēt autonomi jau pēc noklusējuma ierobežo tās operatora spēju īstenot kontroli, līdzīgi kā tas ir paaugstinātas bīstamības avota gadījumā"16.

Norādāms, ka iepriekš citētie viedokḷi vairāk vai mazāk saskan ar šobrīd pastāvošo Eiropas Savienības institūciju redzējumu par primāro veidu, kādā būtu nepieciešams izvērtēt konkrētas personas civiltiesiskās atbildības apmēru, ja tas ir saistīts ar mākslīgā intelekta vadītas sistēmas nodarītu kaitējumu. Vienlaikus arī, autora ieskatā, attiecīgo kategoriju lietās ar civiltiesiskās atbildības piemērošanu saistītie jautājumi būtu izvērtējami stingrās atbildības modelī, tādējādi civiltiesisko atbildību piemērojot gadījumā, ja ir konstatējama mākslīgā intelekta vadìtai sistēmai raksturīgā riska materializēšanās, kas ir atzīstams par cēloni nodarītajam kaitējumam, un nevis, piemēram, mākslīgā intelekta vadìtas sistēmas operatora rīcības neatbilstỉba saprātīgas personas standartam. Turklāt bez ievērības nevar atstāt to, ka mākslīgā intelekta vadìtu sistēmu iespējama ekspluatēšana, piemēram, transporta, medicīnas vai energètikas nozarē, pēc būtības ir saistāma ar paaugstinātu bīstamību citām personām.

Jāṇem vērā, ka vēsturiski īpaša regulējuma nepieciešamība galvenokārt tika pamatota ar Eiropas Komisijas secinājumu par turpmākajām mākslīgā intelekta nozares attīstības tendencēm un potenciālajiem ieguvumiem sabiedrības interesēs. ${ }^{17}$ Minētais savukārt ir rezultējies ne tikai ar dažādiem Eiropas Komisijas

\footnotetext{
${ }^{14}$ Kārkliņš J. Idea of Strict Liability in Private Law. LU žurnāls “Juridiskā zinātne”, Nr. 10. Rīga: LU, 2017, p. 182.

15 Autora intervija ar profesoru Dr. iur. Jāni Kārkliṇu. Rīgā, 20.11.2020. No autora personiskā arhīva.

16 Autora intervija ar docentu Dr. iur. Erlenu Kalniņu. Rīgā, 26.11.2020. No autora personiskā arhīva.

17 Sk. sìkāk: European Commission. Artificial Intelligence for Europe: COM(2018)237. Brussels, 2018. Pieejams: https://ec.europa.eu/digital-single-market/en/news/communication-artificial-intelligenceeurope [aplūkots 20.02.2021.]; sk. arī: European Commission. On Artificial Intelligence - A European approach to excellence and trust: $\operatorname{COM}(2020) 65$. Brussels, 2020. Pieejams: https:/ec.europa.eu/info/sites/ info/files/commission-white-paper-artificial-intelligence-feb2020_en.pdf [aplūkots 20.02.2021.].
} 
ierosinājumiem turpmāku investīciju piesaistei ${ }^{18}$ un vadlīnijām uzticamu mākslīgā intelekta vadìtu sistēmu izstrādei, ${ }^{19}$ bet arī ar secinājumu par to, ka esošie civiltiesiskās atbildības modeḷi mākslīgā intelekta vadītu sistēmu kategoriju lietās ir pilnveidojami. ${ }^{20}$

Pēdējos trīs gados apzinātā problemātika ir bijusi pamats 2020. gada izskaņā publicētam Eiropas Parlamenta ziṇojumam par mākslīgā intelekta vadītām sistēmām piemērojamo civiltiesiskās atbildības režìmu ("Priekšlikums"), ${ }^{21}$ uz kura pamata pārskatāmā periodā nākotnē regulas veidā ir paredzēts noteikt vienotu civiltiesiskās atbildības piemērošanas metodiku, ja kaitējumu ir radījusi mākslīgā intelekta vadīta sistēma. Vienlaikus, lai arī līdz 2021. gada pirmā ceturkšņa beigām Eiropas Komisijai ir jānāk klajā ar iespējamiem Priekšlikuma papildinājumiem, pieņemams, ka tie saturiskā ziṇā ievērojami nemainīs šobrīd publicēto Priekšlikuma redakciju.

\section{Iespējamā regulējuma saturs}

Pirms pievērsties turpmākam Priekšlikuma saturiskajam izvērtējumam, autors uzskata par lietderīgu pavisam īsi pakavēties pie jēdziena "mākslīgais intelekts" izpratnes. Skaidrības nolūkos norādāms, ka mākslīgā intelekta jēdziens var tikt saistīts ar vairākām nozīmēm, jo no tā definēšanas pirmsākumiem, kas aizsākās 20. gadsimta otrajā pusē, ar minēto jēdzienu šobrīd apzīmē ne tikai datorzinātnes apakšnozari, kurā tiek pētīta intelektuālas uzvedības automatizācijas iespējamība, izmantojot datorprogrammas, ${ }^{22}$ bet arī noteikta veida datorizētas sistēmas, kuras to autonomā darbībā var sasniegt noteiktu mērḳi bez citas personas iesaistes. ${ }^{23}$ Turpmāk rakstā jēdziens "mākslīgais intelekts" tiks attiecināts uz noteikta veida datorizētām sistēmām, ar kuru ekspluatēšanu saistītos civiltiesiskās atbildības piemērošanas jautājumus ir paredzēts regulēt ar Priekšlikuma noteikumu starpniecību.

Svarīgi minēt, ka saskaṇā ar Priekšlikuma noteikumiem iespējamais nākotnes regulējums nebūs attiecināms uz ikvienu datorizētu sistēmu, kuras pamatdarbība

18 Sk. sīkāk: European Commission. Policy and investment recommendations for thrustworthy AI. Brussels, 2019. Pieejams: https://ec.europa.eu/digital-single-market/en/news/policy-and-investment-recommendations-trustworthy-artificial-intelligence [aplūkots 20.02.2021.].

19 Sk. sīkāk: European Commission. Ethics guidelines for thrustworthy AI. Brussels, 2019. Pieejams: https:// ec.europa.eu/digital-single-market/en/news/ethics-guidelines-trustworthy-ai [aplūkots 20.02.2021.]; sk. arī: European Commission. The assesment list for thrustworthy artificial intelligence. Brussels, 2020. Pieejams: https://ec.europa.eu/digital-single-market/en/news/assessment-list-trustworthy-artificial-intelligence-altai-self-assessment [aplūkots 20.02.2021.].

${ }^{20}$ European Commission. Liability for emerging digital technologies: SWD(2018)137. Brussels, 2018. Pieejams: https://ec.europa.eu/digital-single-market/en/news/european-commission-staff-working-document-liability-emerging-digital-technologies [aplūkots 20.02.2021.].

${ }^{21}$ European Parliament. Report with recommendations to the Commission on a civil liability regime for artificial intelligence: 2020/2014(INL). Brussels, 2020. Pieejams: https://www.europarl.europa.eu/doceo/ document/A-9-2020-0178_EN.html [aplūkots 20.02.2021.].

22 Nacionālā enciklopēdija. Mākslīgais intelekts. Pieejams: https://enciklopedija.lv/skirklis/24447m\%C4\%81ksl\%C4\%ABgais-intelekts [aplūkots 06.04.2021.]; sk. arī: Smith C., McGuire B., Huang T. The History of Artificial Intelligence. University of Washington, 2006, p. 4. Pieejams: https://courses. cs.washington.edu/courses/csep590/06au/projects/history-ai.pdf [aplūkots 06.04.2021.].

${ }^{23}$ Eurpean Commission. Communication from the Commission: Artificial Intelligence from Europe. Brussels, 2018. p. 1. Pieejams: https://eur-lex.europa.eu/legal-content/EN/TXT/PDF/?uri=CELEX:52018DC0 237\&from=EN [aplūkots 06.04.2021.]. 
saistāma ar zināmu autonomijas pakāpi. Priekšlikuma preambulas apsvērumi visnotaḷ skaidri noteic, ka tādi jēdzieni kā "automatizētu lēmumu pien̦emšana" un "mākslīgais intelekts” ir savstarpēji noškirami, jo automatizētu lēmumu pieņemšana ir saistīta ar to, ka lietotājs jau sākotnēji pilnībā vai daḷēji delegée lēmumu pieņemšanas iespējamību datorizētai sistēmai, kura konkrēto darbību izpilda saskaņā ar jau pastāvošiem "lēmumu pieņemšanas model̦iem". ${ }^{24}$ Tādējādi, lai arī automatizēta lēmumu pieņemšana ir saistāma ar zināmu autonomiju, iespējamais iznākums ir atkarīgs no jau pastāvošiem lēmumu pien̦emšanas modeḷiem, kas savukārt minētos jēdzienus liedz atzìt par sinonīmiem. Mākslīgā intelekta vadītas sistēmas gadījumā situācija ir citāda, jo mākslīgā intelekta vadītas sistēmas darbība nav aprobežojama ar konkrētu "lēmumu pieņemšanas modeli”, bet gan ar mašìnmācības (machine-learning - angḷu val.) jeb pašmācības ceḷā iegūto un apstrādāto informācijas kopumu.

Vienlaikus arī juridiskajā literatūrā pausts viedoklis, ka jēdzienu "mākslīgais intelekts" būtu pamatoti attiecināt uz cilvēka radīām sistēmām, kuru autonomā darbība var tikt patstāvīgi mainīta un pilnībā atšḳirties no tās sākotnējā algoritma uzbūves, un rezultātā šì cilvēka intelektam līdzīgā sistēma mašīnmācības ceḷā ir spējīga pieṇemt patstāvīgus, iepriekš neparedzamus lēmumus bez citas personas iesaistes vairākos savstarpēji nesaistîtos uzdevumu laukos. ${ }^{25}$ Jāṇem vērā, ka šāds minētā jēdziena skaidrojums vismaz pagaidām ir atzīstams par atbilstošu Priekšlikuma 3. panta (a) punktā noteiktajam "mākslīgā intelekta" skaidrojumam. Saskaņā ar to par mākslīgā intelekta vadītu sistēmu ir atzīstama tāda sistēma, "[..] kuras pamatā ir programmatūra vai kura ir iestrādāta ierīcēs un kuras uzvedība imitē intelektu, inter alia, vācot un apstrādājot datus, analizējot un interpretējot apkārtējo vidi un veicot darbības ar zināmu autonomijas pakāpi, lai sasniegtu konkrētus mērḳus”. Tādējādi secināms, ka Priekšlikuma noteikumus ir paredzēts attiecināt nevis uz ikvienu datorizētu sistēmu, kuras darbībā ir konstatējama zināma autonomijas pakāpe, bet gan vienīgi uz tādām datorizētām sistēmām, kuru darbība ir spējīga imitēt cilvēka intelektu, tādējādi iespējamā lēmuma saturu jebkādā veidā neaprobežojot ar jau sākotnēji noteiktu lēmumu pieņemšanas modeli, kas savukārt noteiktu, kādā veidā iegūtā un apstrādātā informācija ir interpretējama.

Vienlaikus, apzinoties ar Priekšlikumu piedāvātā iespējamā regulējuma tvērumu, būtiski minēt, ka atbilstoši Priekšlikuma noteikumiem civiltiesiskā atbildība par mākslīgā intelekta vadītas sistēmas nodarītu kaitējumu trešajai personai būs izvērtējama gan vainojamības modelī, gan stingrās atbildības modelī. Vienīgais kritērijs, lai nošķirtu, kurš no minētajiem civiltiesiskās atbildības modeḷiem ir piemērojams iespējama kaitējuma gadījumā, ir mākslīgā intelekta vadìtas sistēmas "riska" kategorija, kuru rada tās lietošana. ${ }^{26}$ Citiem vārdiem, saskaṇā ar Priekšlikuma noteikumiem ir paredzēts, ka "augsta” riska mākslīgā intelekta vadītas sistēmas operatoru civiltiesiskā atbildība būtu izvērtējama ar stingrās atbildības modeḷa starpniecību, savukārt tādu mākslīgā intelekta vadītu

${ }^{24}$ European Parliament. Report with recommendations to the Commission on a civil liability regime for artificial intelligence: 2020/2014(INL). Brussels, 2020, recital (G). Pieejams: https://www.europarl. europa.eu/doceo/document/A-9-2020-0178_EN.html [aplūkots 20.02.2021.].

25 Sk. sīkāk: Kārklinš̌ J., Purmalis R. 2020, 245. lpp.

${ }^{26}$ European Parliament. Report with recommendations to the Commission on a civil liability regime for artificial intelligence: 2020/2014(INL). Brussels, 2020, recital 14. Pieejams: https://www.europarl.europa. eu/doceo/document/A-9-2020-0178_EN.html [aplūkots 20.02.2021.]. 
sistēmu operatoru civiltiesiskā atbildība, kas neietilpst minētajā "augsta" riska kategorijā, - ar vainojamības model̦a starpniecību. Ja mēs raugāmies uz Priekšlikuma 15. apsvērumu, tad varam secināt, ka "augsts" risks ir konstatējams tad, ja mākslīgā intelekta vadītas sistēmas "autonomajai darbībai piemìt ievērojams potenciāls radīt kaitējumu vienai vai vairākām personām tādā veidā, kas ir nejaušs un pārsniedz to, ko varētu pamatoti sagaidīt”. Lìdz ar to, ja mākslīgā intelekta vadītas sistēmas ekspluatēšanā var konstatēt ievērojamu kaitējuma nodarī̌sanas potenciālu, kas turklāt ir nejaušs un objektīvi neparedzams, mākslīgā intelekta vadìtas sistēmas operatora civiltiesiskā atbildība ir izvērtējama stingrās atbildības ietvaros.

Minētā kontekstā norādāms, ka hipotētiski liela daḷa mākslīgā intelekta vadītu sistēmu var radīt kaitējumu "vienai vai vairākām personām" veidā, kas turklāt "ir nejaušs un pārsniedz to, ko varētu pamatoti sagaidīt". Tādēl, autora ieskatā, minēto kritēriju būtu lietderīgi papildināt, nosakot, ka "augsta" riska kritērijs ir konstatējams ikvienā dzīves situācijā, ja mākslīgā intelekta vadīta sistēma tiek ekspluatēta stratēgiski svarīgās, piemēram, medicīnas, transporta, energètikas u. c., nozarēs. Šādas pieejas rezultātā jau priekšlaicīgi varētu nodrošināt, ka tiktu izslēgtas (vai ievērojami minimizētas) diskusijas par to, vai un cik l’oti kādas mākslīgā intelekta vadītas sistēmas ekspluatēšana ir saistāma ar jau minēto "augsta" riska pazīmi.

Tāpat, kā to paredz Priekšlikuma 4. panta 4. punkts, ikvienai “augsta” riska mākslīgā intelekta vadītai sistēmai būs jābūt spēkā esošai civiltiesiskās atbildības apdrošināšanas polisei. Ir pavisam skaidrs, ka tādējādi ir iecerēts sekmēt iespējamo kaitējumu cietušās personas tiesiskās intereses. Tomēr bez ievērības nevar atstāt to, ka Priekšlikuma noteikumu pašreizējā redakcija neparedz nedz soda sankcijas, nedz arī cita veida mehānismus, kuru lietošanas rezultātā varētu tikt ierobežota tādas "augsta" riska mākslīgā intelekta vadītas sistēmas turpmāka ekspluatēšana, kurai, pretēji Priekšlikuma noteikumiem, nav spēkā esošas civiltiesiskās apdrošināšanas polises. Autora ieskatā, minēto soda sankciju vai cita veida ekspluatēšanas ierobežojumu neesamība vērtējama kā zināma nepilnība, kuru būtu lietderīgi novērst. Turklāt minēto ierobežojumu neesamības gadỉjumā nevarēs izslēgt tādu situāciju rašanos, kurās cietušajai personai, pretēji Priekšlikuma sadaḷas "apdrošināšana un MI [mākslīgā intelekta - autora piebilde] sistēmas" 24. apsvērumā noteiktajam, tiek radīts papildu apgrūtinājums saṇemt kompensāciju par minētajai personai nodarīto kaitējumu. Lai arī pirmšķietami varētu pieņemt, ka šādas situācijas būtu risināmas ar jau Priekšlikumā pieminētajiem kompensācijas fondiem, jāṇem vērā, ka, saskaṇā ar Priekšlikuma 22. apsvērumu, minēto fondu izveides pamats ir saistāms ar "augsta" riska mākslīgā intelekta vadītas sistēmas darbības rezultātā nodarītu kolektīvu kaitējumu, turklāt apmērā, kas ievērojami pārsniegtu Priekšlikumā noteiktos kaitējuma apmērus, vai arī ar situāciju, kad kaitējumu nodarījusi tāda mākslīgā intelekta vadìta sistēma, kas vēl nav bijusi klasificēta kā "augsta" riska un tādējādi bijusi bez spēkā esošas obligātās civiltiesiskās apdrošināšanas polises.

Tāpat jāṇem vērā, ka saskaņā ar Priekšlikuma 6. panta 1. punktu “augsta” riska mākslīgā intelekta vadītas sistēmas operatoram cita starpā tiks izvirzìts papildu pienākums attiecībā uz uzturlīdzekḷu izmaksu personai, kuru kaitējumu cietušajai (mirušajai) personai ir bijis juridisks pienākums uzturēt. Tomēr jābilst, ka pašreizējā Priekšlikuma redakcija neparedz pietiekami skaidru metodiku minēto uzturlīdzekḷu apmēra noteikšanai, kā tik vien satur norādi, ka "[..] atbildīgais operators 
atlīdzina maksājumus šai trešajai pusei, izmaksājot uzturlīizekḷus tādā apmērā, kādā skartajai personai būtu bijis pienākums maksāt, par laikposmu, kas atbilst šāda vecuma un vispārējā apraksta personas paredzamajam mūža ilgumam". Pavisam iespējams, ka izmaksājamo uzturlīdzekḷu apmērs varētu tikt noteikts atbilstoši kaitējumu cietušās (mirušās) personas labklājības stāvoklim un nevis kaitējumu cietušās (mirušās) personas mìtnes valsts normatīvajos aktos noteiktajām minimālajām uzturlīdzekḷu apmēra proporcijām.

Vienlaikus, kā to paredz Priekšlikuma 7. panta 1. punkts, tad "augsta” riska mākslīgā intelekta vadītas sistēmas rezultātā nodarīts kaitējums, kas ir rezultējies ar personas nāvi, kaitējumu tās veselïbai vai fiziskajai neaizskaramībai, ir pakḷauts trīsdesmit gadu noilguma periodam. Lai arī minētais noilguma periods nenoliedzami kalpo kaitējumu cietušās personas tiesisko interešu nodrošināšanai, atsevišķi izvērtējams, vai šāda paildzināta noilguma perioda esamība ilgtermiṇā neradīs negatīvu ietekmi uz tiesisko noteiktību. Savukārt citos gadījumos, kad kaitējumu nav radījusi "augsta" riska mākslīgā intelekta vadìta sistēma, atbilstoši Priekšlikuma 9. pantam kaitējuma apmērus un piemērojamos noilguma termiņus regulēs tās Eiropas Savienības dalībvalsts normatīvais regulējums, kurā persona cietusi kaitējumu.

Rezumējot minēto, var atzīt, ka pašreizējā Priekšlikuma redakcija kopumā ir vērtējama kā visnotaḷ novatoriska, turklāt ar tās starpniecību "augsta" riska mākslīgā intelekta vadītu sistēmu operatoriem tiek izvirzītas īpašas prasības ne tikai attiecībā uz obligāto civiltiesisko apdrošināšanu un iespējamu pienākumu veikt uzturlīdzekḷu izmaksu, bet arī uz minēto sistēmu operatoru pakḷaušanu ievērojamam noilguma periodam gadījumā, ja minētās sistēmas darbība ir rezultējusies ar kaitējumu citai personai. Vienlaikus, lai arī saskaṇā ar Priekšlikuma noteikumiem pret “zema” riska mākslīgā intelekta vadītu sistēmu operatoriem darbosies vainojamības prezumpcija, autora ieskatā, tas jebkādā veidā nemaina situāciju ar jau raksta sākuma daḷā paustajiem apsvērumiem par vainojamības modelī īstenojamo saprātīgas personas standarta izvērtējumu, nemaz nerunājot par tā iespējamu attiecināšanu uz personu, kuras pārraudzībā (tiešā vai netiešā kontrolē) ir sistēma, kas jau pēc noklusējuma ir radīta, lai funkcionētu autonomi.

\section{Kopsavilkums}

1. Priekšlikums un ar to piedāvātais regulējums civiltiesiskās atbildības piemērošanas metodikai mākslīgā intelekta vadītu sistēmu nodarìta kaitējuma gadījumā kopumā ir vērtējams kā pozitīvs risinājums līdzšinēji pastāvošajai nenoteiktîbai attiecībā uz ìpaša regulējuma neesamību, tomēr bez ievērības nevar atstāt to, ka pašreizējā Priekšlikuma redakcija nesatur pietiekami skaidras vadlīnijas "zema" riska mākslīgā intelekta vadìtas sistēmas operatora "rūpibas standarta” tvēruma noteikšanai. Minētais savukārt varētu negatīvi ietekmēt civiltiesiskās atbildības piemērošanas iespējamību vainojamības modelī.

2. Lai arī Priekšlikuma noteikumi “augsta” riska mākslīgā intelekta vadìtām sistēmām izvirza prasību pēc obligātas civiltiesiskās apdrošināšanas polises, Priekšlikuma noteikumi neparedz īpašus piespiedu mehānismus, kādā varētu tikt ierobežota vai izslēgta "augsta” riska mākslīgā intelekta vadītu sistēmu 
ekspluatēšana gadījumā, ja minēto prasību šādu sistēmu operators neievēro. Lai arī varētu uzskatīt, ka iespējamo negatīvo seku gadījumā iespējamos prasījumus par nodarītā kaitējuma kompensāciju varētu adresēt kompensācijas fondiem (ja tādi tiktu izveidoti atbilstoši Priekšlikumā noteiktajam), tas izrietētu ārpus minēto kompensācijas fondu izveides mērķa.

3. Lai priekšlaicīgi novērstu iespējamu kazuistiku saistībā ar mākslīgā intelekta vadītu sistēmu klasifikāciju Priekšlikumā minētajās riska kategorijās, Priekšlikumā minētā "augsta" riska kategorija būtu konkretizējama turpmāka regulējuma izstrādē, jo hipotētiski liela daļa mākslīgā intelekta vadītu sistēmu var radìt kaitējumu "vienai vai vairākām personām" veidā, kas turklāt "ir nejaušs un pārsniedz to, ko varētu pamatoti sagaidìt". Autora ieskatā, būtu visnotal lietderīgi noteikt, ka "augsta" riska kritērijs ir konstatējams ikvienā dzīves situācijā, ja mākslīgā intelekta vadīta sistēma tiek ekspluatēta stratēgiski svarīgās, piemēram, medicīnas, transporta, energètikas u. c., nozarēs.

4. Atsevišķi izvērtējams un precizējams Priekšlikumā noteiktais "augsta" riska mākslīgā intelekta vadītu sistēmu operatoru pienākums nodrošināt uzturlīdzekḷu izmaksu kaitējumu cietušãs personas dzimušajai vai ieņemtajai atvasei, jo Priekšlikuma noteikumi neparedz īpašas atrunas nedz izmaksājamo uzturlïdzekḷu atskaites punktu, nedz arī metodiku to apmēra noteikšanai. Pavisam iespējams, ka izmaksājamo uzturlïdzekḷu apmērs varētu tikt noteikts atbilstoši kaitējumu cietušās (mirušās) personas labklājības stāvoklim, nevis kaitējumu cietušās (mirušās) personas mītnes valsts normatīvajos aktos noteiktajām minimālajām uzturlīdzekḷu apmēra proporcijām.

5. Atsevišķi izvērtējams un precizējams, vai "augsta" riska mākslīgā intelekta vadìtu sistēmu nodarīts kaitējums dzīvībai, veselībai vai fiziskajai neaizskaramībai tik tiešām ir pakḷaujams trīsdesmit gadu noilguma periodam, jo šāda paildzināta noilguma perioda esamība būtībā varētu nonākt pretrunā ar pastāvošo izpratni par tiesisko noteiktību un par vispārpieņemtām padarīt tiesvedības par nodarītā kaitējuma kompensāciju arī par vairāk kā divdesmit gadu senā pagātnē nodarītu kaitējumu. 